\title{
C-C Chemokine Receptor Type 1
}

National Cancer Institute

\section{Source}

National Cancer Institute. C-C Chemokine Receptor Type 1. NCI Thesaurus. Code C25776.

C-C chemokine receptor type 1 ( $355 \mathrm{aa}, \sim 41 \mathrm{kDa}$ ) is encoded by the human CCR1 gene. This protein plays a role in chemokine-mediated signaling. 